\title{
Telling Stories, Naming Names: Heptaméron 43
}

LAURA DOYLE GATES

Summary: This paper focuses on the idea of the grammatical third person as organizing principle for the 43rd tale of Marguerite de Navarre's Heptaméron. The third person encompasses several relevant domains, among them the assignation of gender, the function of proper names, and Benveniste's notion of "histoire" for storytelling. Exploring the ramifications of the "nom" in and around Heptaméron 43 elucidates characters' and protagonists' apparent obsession with naming and reveals necessary differences between masculine and feminine responses to the courtly imperative to entertain with witty speech and stories.

[La Dame de cour] sera fort propre et avenante à converser, rire, jouer, railler et en toutes choses, et entretiendra proprement de contes et facéties à elle convenables toute personne qui se présentera.

Le parfait courtisan ${ }^{1}$

\begin{abstract}
Castiglione's celebrated work devotes much attention to the specter of boredom that looms large over life at court in the Renaissance. While any ambitious nobleman of the period had to "savoir son Courtisan" (including knowing how to banish boredom with witty speech), Castiglione's description of the ideal "dame de cour" suggests that women too should adopt a social and esthetic role of "entretenement." Because it places new value on feminine speech (turning wit into a requirement), the Courtisan provides a forwardlooking model for aristocratic women, anticipating the moment when skill in "entretenement" will be the pivot of courtly life in France for men and women
\end{abstract}


alike. ${ }^{2}$ The imperative to entertain at court supplements women's traditionallydefined biological and economic destiny: the "dame de cour" is primarily neither mother nor wife since her "principale profession" lies outside the home (Courtisan, p. 238). Certainly, skill in "entretenement" becomes an indispensable quality for the aristocratic women of Marguerite de Navarre's Heptaméron, when five male and five female characters redeem a potentially boring confinement at Serrance by entertaining each other with stories. Yet, despite Hircan's confident assertion that "[A]u jeu nous sommes tous esgaulx" (p. 10), telling entertaining stories is an activity that engages each sex differently. In the pages to follow, I want to study how the courtly imperative to entertain works along gender lines, using the example of Heptaméron 43. This tale is one of the most provocative stories in the collection and features a powerful, active and desiring noblewoman called Jambicque. Jambicque enjoys " 1 'honneur et le plaisir ensemble" (p. 24), sometimes reinforcing, sometimes subverting courtly codes of conduct for women to her own advantage. ${ }^{3}$ Her success stems from her understanding of how these constraints on women relate to the activity of storytelling. Jambicque deliberately sabotages the courtly circuit of entertaining narrative and defers the telling of her own story so successfully that it becomes an obsession to certain other characters. I will analyze her power strategies in terms of the grammatical third person: the linguistic point at which truth is established, gender is conferred, and names are named. The obsession with naming names (and the language of the third person) is manifest both within the story and in the debates of the surrounding frame-tale and points to the crucial relation between the pleasure of stories and stories of pleasure for the Heptaméron.

An array of problems concerning the relation between narrative pleasure and sexual pleasure is already laid out during the Heptaméron prologue in the characters' decision to engage in an activity which will be "plaisant au corps" (like sex), yet provide pleasure for the group as a whole (p. 8). Love-making is rejected as not social enough, yet sexual pleasure is recuperated to a certain extent through narrative pleasure that often depends on the "intimacy" of the material most like to entertain: amorous and humorous tales. However, erotico-comic material is not gender-neutral: often, it works misogynistically by taking women as its objects and its "shamelessness" can implicate the narrator, particularly when the narrator is a woman. ${ }^{4}$ Castiglione hints at the danger women face in being entertaining by specifying that the "dame de cour" must know how to "divertir les autres sans s'exposer au blâme," and by citing the existence of entertaining material "à elle convenable [...]." The reception 
of many Heptaméron tales told by women demonstrates that giving pleasure (by meeting the group's expectations for entertainment) can be tricky: narrative and sexual pleasure are linked in the genre of "recueils de contes." The Italian and French traditions feature "shameless" stories that can "taint" the woman who repeats them through a process of identification. Again in the Courtisan, Castiglione refers to the automatic identification made between a woman's discourse and her "honneur" in storytelling; he cites the case of women who "vont toujours cherchant à connaître les amours des autres et les racontent avec tant de détails et de complaisance" (p. 236). According to Castiglione:

... les hommes, bien qu'il semble qu'ils les écoutent volontiers, ont le plus souvent mauvaise opinion d'elles et ne les respectent guère; il leur paraît qu'avec de telles façons ils sont invités par elles à aller plus loin, et souvent après ils se portent à des excès qui leur donnent une mauvaise réputation méritée, et finalement ils les estiment si peu qu'ils ne recherchent plus leur compagnie, mais au contraire les ont en horreur. . . (pp. 236-237).

Heptaméron 62 is the worst-case scenario of the text for a woman storyteller: a young woman tries to regale some noble ladies with the story of a rape but accidentally reveals that the events she is recounting in the third person are actually her own story (her tongue slips and she uses "je" instead of "elle" for the punch line). Her tale ends up being highly entertaining (first to the female listeners, then to the mixed company of the Heptaméron), but she herself is dishonored by it.

In a recent article that treats this tale in depth, François Cornilliat and Ullrich Langer discuss the pertinence for the Heptaméron of both Castiglione's formulae for witty stories at court (Courtisan, 161-211) and Cicero's account of rhetorical "decorum" (De Officiis I.126-129). ${ }^{5}$ Decorum in speech is based on the way Nature has constructed our bodies: just as she keeps our "shameful parts" hidden, so our discourse should conceal what is shameful about us. Cornilliat and Langer show how the courtly imperative to entertain (often using "shameless" material) and Nature's inclination toward decency come together to explain why entertaining stories are usually told at someone else's expense, in the grammatical third person. Furthermore, rhetorically speaking, what must remain hidden to preserve decency and honor is somewhat different for men and women. In Heptaméron 62, with a slip of the tongue, the young woman reveals that the story of a rape she is telling is actually her own story. As a result, her courtly audience is highly entertained by the spectacle of her 
dishonoring exposure. In contrast to this reckless young woman, Jambicque lucidly understands the mechanisms and dangers of narrative activity, particularly for women. And although her own story is never successfully told (as I will argue), narrative activity itself remains the tale's key theme and main avenue to power. ${ }^{6}$ To tell shameless stories without shaming or dishonoring oneself is thus the imperative that underpins the whole Heptaméron project, and the problem lies with how closely the narrators of stories and the protagonists in stories are identified. The 43rd tale provides a subtle counterpoint or even antidote to the precipitous self-revelation of the 62nd. Here, the courtly imperative to relieve boredom through a certain kind of discourse without dishonor to oneself is again the major theme, but this story demonstrates that male narrators can run into problems of inadvertent identification also.

As in the 62nd tale, the setting of Heptaméron 43 (the circle of a "grande princesse et de grande auctorité" [p. 296]) mirrors to a certain extent the aristocratic society of the "devisants," except that at this court nobles are prevented from entertaining themselves with storytelling by a certain "audatieuse" young woman whose rigid morality leads her to enforce decorous behavior at court. She does tell stories, but these stories are calculated to punish rather than entertain:

Ceste Jambicque reprouvoit tant la folle amour, que, quand elle voyoit quelque gentil homme amoureux de l'une de ses compaignes, elle les reprenoit fort aigrement et en faisoit si mauvais rapport à sa maistresse, que souvent elle les faisoit tanser... (p. 296).

As a consequence, Jambicque is "beaucoup plus craincte que aymée de toute la compaignie," and very much in favor with the princess, who believes her to be "la plus sage et vertueuse damoiselle qui fut poinct de son temps" ( $p$. 296).

Despite her constant denunciation of amorous intrigues, the young woman herself falls violently in love with a certain gentleman. Eventually, she finds a way to preserve her powerful credit and spotless reputation at court while satisfying her passion for the young man. She meets him regularly in the dark gallery "ayant mis sa cornette basse et son touret de nez" and warns him not to seek to find out who she is, at the risk of ending their relationship (p. 297). The man, who ultimately cannot bridle his curiosity, puts a chalk mark on her shoulder during one of their trysts and breaks her anonymity. At first he is content just to know, but then cannot resist letting her know that he knows. He confronts her in broad daylight and urges her to give up "si grande fiction," at 
least with him, and to concur with his version of events, a version in which she is the main protagonist (p. 299). However, the incensed young woman makes a "grand signe de croix" and has him banished from court, without ever giving the slightest indication she knows what he is talking about. The gentleman "ne onques ne puys n'oyt nouvelles de celle qui luy avoit bien promis qu'il la perdroit, de l'heure qu'il la chercheroit" (p. 300).

As we see, Jambicque systematically opposes gossip and storytelling at court, aware that societal norms situate men and women differently with respect to these pastimes. Through certain types of narration, men acquire and preserve honor and power (particularly through stories of successful seduction). A man can be identified with the desiring male protagonist of a narrative without shame or loss of honor. Women, on the other hand, gain honor and power by making sure they themselves are never identified with desiring female protagonists and never play a role in such tales.

The concrete consequences of the courtly activities of gossiping and storytelling (pleasure for all, danger for women, glory for men) reside at least partially in the naming of names. Naturally, narrative activity has fewer repercussions when names are not associated with the stories' protagonists, but when less is revealed, there is often less pleasure. In the 43rd tale, the grammatical category of the third person (the "nom," names, pronouns) is at stake. This linguistic slot covers an array of related ideas. First of all, the idea of "name" can be extended to the idea of "reputation." One's good name, "la renommée," is all-important for success and honor at court. Second, the grammatical third person is the linguistic locus where truth-values may be assigned to statements. As Émile Benvéniste points out, the referents of thirdperson pronouns remain constant in French and do not shift as do those of "je" and "tu." The special status of the third person is fundamental to the whole project of the Heptaméron - telling true stories about other people - and is equally important to the organization of the $43 \mathrm{rd}$ tale. Finally, the grammatical third person functions as the point at which gender is formally assigned in the language of the text, since it is nearly impossible to speak of someone without specifying whether the person is a man or a woman. The 43rd tale and surrounding debate reveal an obsession with naming, re-naming and unnaming Jambicque. There is a triple quest for power through controlling this name, undertaken by Geburon as narrator, by Jambicque herself and by the young man in the story. ${ }^{8}$ Thus, the 43 rd tale represents a moment in the Heptaméron when the idea of naming (objectifying, representing, conferring gender) becomes extremely critical. 
In the Heptaméron, proper names of protagonists are often concealed or changed by the narrators to protect identities, a practice that does not necessarily compromise the required truthfulness of the tale (as Gisèle MathieuCastellani points out, cryptonymy can be itself an "argument d'authenticité" ${ }^{\text {) }}$. In fact, names may be poetically (rather than historically) motivated: they can not only denote but signify in a variety of ways, from functioning as pretexts for word play to providing interpretive signals that invite the reader (as François Rigolot says) to "saisir de biais l'idéologie du texte."10 The 43rd tale provides a highly intriguing example of poetic onomastics: the narrator Geburon imposes an indelicate and implausible substitute name upon the main protagonist. He proposes to speak of "une damoiselle, de laquele, pour l'honneur de la race, je changeroy le nom, et la nommeroy Jambicque"(p. 296). Geburon is trying to make his tale more compelling: the name he chooses successfully reinforces the intended message of his story: his announcements about her character in the preface match the reactions of the other devisants after he finishes the story. Jambicque's name is meant to be as offensive as she is and to overdetermine the audience's reception of the story of her actions. Geburon plays on at least two associations of the word "jambe." First, this young woman is "vaincue . . . en plaisir," dominated by the lower body. Second, the young woman's two separate identities are emphasized: she is pronounced hypocritical, "double" and deserving of "double infamy" (p. 301).

Geburon apparently wants to accomplish two goals with this story, each requiring a different rhetorical strategy. However, his renaming of the "damoiselle" accomplishes one goal while undermining the other, and becomes a rather contradictory technique that reveals his lack of control over her story. First, Geburon wants to astonish and entertain the Heptaméron group by recounting the young woman's wicked character and actions. Renaming her "Jambicque" lays bare and poetically reinforces the idea of her "folye" and hypocrisy. This is the domain of epideictic or demonstrative rhetoric which, according to Quintilian, "develops all the resources of eloquence and deploys all its ornaments." justice by revealing her guilty secret (recounting "son histoire où la verité sera dicte tout au long" [p. 296]). He declares at the end of his story that now she has effectively lost her honor: "[A]ujourd'hui est leu aux oeilz d'un chascun ce qu'elle vouloit cacher à ceulx de son amy, et, fuyant la mocquery d'un, est tombé en la mocquery de tous" (pp. 300-301). The goal of punishing the "damoiselle" through relating the truth of her actions, through presenting evidence that she did indeed commit certain "crimes," falls into the domain of 
judicial rhetoric, and has to do with convincing an audience (judge and jury) of how things happened in the past and what to do about it now. Geburon's poeticization of the young woman's name (which uses the "beaulté de la rethoricque" [p. 9]) seems to contradict his avowed project of bringing the young woman to justice, for without naming her real name, the story cannot work to dishonor her in any concrete way.

Jambicque, in contrast, is consistent. She refuses all complicity with a narrative which she herself does not control and thus disobeys the courtly imperative to be agreeable and entertaining. Rather than play a game she (as a woman) cannot win and rather than incur the loss of her power, she prefers being "beaucoup plus craincte que aymée de toute la compaignie" (p. 296). She tells her tales to the princess alone and thereby makes sure that courtly society will have nothing to talk about, for any "histoires" are nipped in the bud by the princess's scolding. Not only does Jambicque protect other women from becoming the subject matter of some amorous tale, she is also able to squelch any temptation other people might feel to discuss her own behavior with men: "quant à elle, jamois ne parloit à homme, sinon tout haut et avecq une grande audace" ( $p$. 296). What would be entertaining about repeating a scene that the "damoiselle" has already broadcast to the whole room? Finally, knowledge of her name (and the power it confers to tell a tale about her) is the one thing she refuses the "gentil homme": "[S]i vous me voulez promectre de m'aymer et de jamois n'en parler à personne, ne vous enquerir de moy qui je suy. . . je vous seray loyalle et bonne amye. .." (p. 297). She resists satisfying her passion in a socially acceptable manner, "par le regard et la parolle," because then she would be just a third-person object at the mercy of "le regard et la parolle" of others at court.

In the debate following the 43rd tale, it is easy to see that "Jambicque" is a prototype of the bad storyteller, a person who would be implicitly as unwelcome in the Heptaméron circle as the explicitly excluded monks and lower classes. Parlamente can hardly imagine such a woman, and provocatively, operates yet another change of name for Jambicque. Parlamente remarks that "celles qui sont vaincues en plaisir [like Jambicque] ne se doibvent plus nommer femmes, mais hommes, desquelz la fureur et la concupiscence augmente leur honneur" (p. 301). She observes that Jambicque has exceeded her gender identity and it is clear that her refusal to occupy the place of the grammatical third person in someone else's discourse represents a refusal of the limitations this linguistic slots assigns. Indeed, once free of her name she is free to take on a more masculine role; her resulting gender indeterminacy (elegantly analyzed by Hope Glidden ${ }^{12}$ ) is the main factor in the 
young gentleman's increasing dissatisfaction with their "amityé." Jambicque usurps the traditionally male role of making the first move and the man, although amazed at his good fortune in their immediate satisfaction of physical desire, tells her: "J'estime beaucoup le bien que ... vous m'avez donné, mays j'estimeray plus celluy que j' auray de vous à ma requeste..." (p. 298). In order to enjoy fully the "plaisir" of their relationship, he must be able to "pourchasser." No wonder he ends up confused, since according to Simontault the masculine role is to "pourchasser les femmes, car Dieu a mis au coeur de l'homme l'amour et la hardiesse pour demander, et en celluy de la femme la crainte et la chasteté pour refuser" (p. 279). But Jambicque short-circuits this desire, and explains that she will summon him, using a code phrase that refers to his promise to respect the anonymity that ensures her freedom from gender confines $!^{13}$ Jambicque retains control, for any power he could gain over her would reside in his ability to name her. The gentleman's frustration at not knowing his lover's name can be traced back to a source which he refuses to perceive. Instead, he has recourse to a supernatural explanation of it:

Et continuerent longuement ceste vie, sans qu'il s'apperceust jamays qui elle estoit: dont il entra en une grande fantaisye. . . car il ne pensoit poinct qu'il y eut femme au monde qui ne voullut estre vue et aymée. Et se doubta que ce fust quelque maling esperit. . (p. 298).

In his reasoning ("une grande fantaisye"), his lover could not be a woman, for all women want to be viewed and loved. Therefore, she must be some sort of devil or witch. But we see that the gender indeterminacy enjoyed by Jambicque has caused him to doubt his masculinity. He is not really so innocent that he cannot imagine a woman as "hypocritical" as Jambicque - he simply cannot imagine himself in such a de-masculinized position. Glidden characterizes his fantasizing as the "self-serving exercise of his own narcissistic need to be affirmed in his identity as a courtly lover."14

This brings us to a fuller understanding of his dissatisfaction with their relationship. According to Parlamente's formulation, he is a man whose "fureur et concupiscence" supposedly increase his "honneur." Parlamente does not make explicit exactly how men's honor is increased but presumably it is through stories. Narrative activity presents a supplementary "plaisir" for men - making love can be enjoyed in itself and its pleasure can be prolonged later by articulating it in language. Montaigne, for example, speaks of "le plaisir d'en compter . . . qui ne doit guere en douceur à celuy mesme de l'effet," 15 but the same story which aggrandizes the man's reputation dimin- 
ishes the woman's. Men thus have access to a powerful supplementary pleasure to which women do not, or only indirectly. More pertinently for the 43rd tale, the gentleman's malaise suggests that it can be difficult to live a love affair in isolation: gender roles lack societal affirmation because the affair remains unarticulated in the language of the third person.

Rather than take her at her word ("j'aymerois mieux morir, que vous sceussiez qui je suys"[p. 297] and "je vous prye ne serchez jamays de me congnoistre, si vous ne voulez la separation de nostre amytié" [p. 298]), the gentleman cannot help but interpret her "no" as a "yes," fatuously believing that "quant [son amour] seroit congneue, elle auroit occasion d'augmenter" (p. 299). What is interesting here is that the feminine "no" (which in the Heptaméron is most often a spur to masculine desire that need not distinguish between the pleasures of love and the pleasures of narrative) provokes masculine desire of a different order. Jambicque says "yes" immediately to sexual relations, thus depriving the man of the pleasure of the chase, of forcing a "no" to become a "yes," of conquering the woman. The "gentil homme" refuses to interpret Jambicque's only "no" as a "no," in order to offer himself the pleasure of another kind of victory, where the sexual has been displaced onto the narrative. As Longarine says elsewhere, "il n'y a veneur qui ne prenne plaisir à corner sa prise, ny amoureulx d'avoir la gloire de sa victoire" (p. 322). His inability to tell the tale of his conquest calls into question whether he made it: he must write Jambicque into a more traditional script.

At their final confrontation, the young man teases Jambicque, then laughingly enjoins her to give up her "si grande fiction" (p. 299). He wants her to acknowledge her role in the masculine story he began "writing" with the chalk mark on her back. However, she refuses to be intimidated into an identification, into collapsing her public identity with that of the potentially objectified woman in his account. Since he cannot persuade her to admit that she sees herself in his narrative, his story is a failure and she is able to maintain and even reinforce her position of power. Her credit is such that he is banished from court (the text specifies "sans parler à personne" [p. 300]) and the outcome leaves little doubt as to which is the more important to Jambicque: power or pleasure, "sa gloire et reputation" or "son affection" (p. 297). In the end, her total control of the grammatical third person as it relates to her prevents him from using it to protect his own position at court.

The failure of the young man's narrative to trap Jambicque and his inability to articulate what he knows in order to save his own reputation are mirrored in the false bravado of Geburon's seemingly triumphant conclusion: 
Parquoy, mesdames, povez veoir comme celle qui avoit preferé la gloire du monde à sa conscience, a perdu l'un et l'autre, car aujourd'huy est leu aux oeilz d'un chascun ce qu'elle vouloit cacher à ceulx de son amy, et, fuyant la mocquery d'un, est tombé en la mocquery de tous (pp. 300-301).

Who is the "elle" in question and exactly how has her honor been publicly stripped? It would seem that effective retribution through public dishonor would necessitate the revelation of her name or some other validation of her identity. While the Heptaméron often does not name names, there is usually a witness within each story who sees the protagonist's exposure and thus guarantees its authenticity (like the circle of women in Heptaméron 62). Todorov discusses this "problème du témoin" with respect to the Decameron: "Boccace a le souci de toujours introduire un personnage... qui sert de témoin, et avec qui le lecteur peut s'identifier. . . L'éclat de rire du lecteur doit être présenté à l' intérieur de la nouvelle." ${ }^{.6}$ Lyons and McKinley consider a similar form of witnessing in Marguerite de Navarre's text: "From the beginning, the Heptaméron stories are intended to include some validating account of the relay between an event. . . and its disclosure at the storytellers' circle." ${ }^{17}$ The requisite witness is absent from Heptaméron 43: there is some gap in transmission, such that we have only Geburon's word that his story effectively punishes the young woman. We wonder why he undermines the whole thrust of his tale by disguising her real name. How did he come to know the story? Without affirming that Geburon is telling his own story in the third person (like the imprudent young woman in Heptaméron 62), it seems certain that the failure within the 43rd tale of the young man's discourse to pin guilt on Jambicque is doubled by the failure of Geburon's narrative at the level of the frame-tale. Jambicque's story comes to us across a narrative void that subtly undermines its intended message. For while Geburon's audience is successfully astonished by the audacity of such a woman, this does not mean that any particular woman is dishonored, as Geburon claims.

Montaigne says, "Il y a jouissance ailleurs que dans la jouissance," 18 and we have seen how the power and pleasure offered by the narrative can become even more important and obsessive than sexual pleasure itself. Narrative pleasure often requires that protagonists of tales be objectified by the grammatical third person. As a consequence, they must take on gender, an identity both linguistically and socially constructed. This identity constrains women and men in different ways, but linguistically and socially speaking, the feminine is always the "marked" case. Jambicque refuses to be "marked" and 
her story demonstrates that two people in a relationship - a je and a $t u$ - can have sex without the objectified gender that third-person names imply. But for Jambicque's chosen "gentil homme," sex was not enough.

\section{Providence, Rhode Island, USA}

\section{Notes}

1. Le parfait courtisan de Baltasar Castillonois, trans. Gabriel Chappuys, 1585, reproduced in J.- P. and Luce Guillerm, eds. Le miroir des femmes: moralistes et polémistes au XVI siècle, 2 vols. (Lille: Presses Universitaires de Lille, 1983-1984), I, p. 160. From here on I will use the modern translation based on Chappuys by André Pons (Paris: Flammarion, 1991).

2. Guillerm, I, p. 155.

3. All quotations of the Heptaméron are taken from the edition of Michel François (Paris: Classiques Garnier, 1967).

4. As Nicole Cazauran notes, tales in the Heptaméron mostly concern amorous activity, where the woman's objectification is apparent in the social organization of amorous behavior: the man is typically the active force, and, at the moment she becomes active, the woman's desire is exposed, leaving her open to society's censure. Cf. L'"Heptaméron" de Marguerite de Navarre (Paris: SEDES-CDU, 1976; 1991). Freud discusses the antifeminism of certain kinds of comedy in his Jokes and their Relation to the Unconscious. "Tendentious" jokes and witticisms work at the expense of women by producing a shameful exposure of feminine sexual desire (trans. James Strachey [New York: Norton, 1960], pp. 115-121).

5. "Naked Narrator: Heptaméron 62," in John D. Lyons and Mary B. McKinley, eds. Critical Tales: New Studies of the "Heptameron" and Early Modern Culture (Philadelphia: University of Pennsylvania Press, 1993), 123-145. Colette Winn also discusses the antinarrative message of the Heptaméron for women in "'LaLoidu non-parler' dans l' Heptaméron de Marguerite de Navarre," Romance Quarterly, 33 (1986): 157-168.

6. In her article, "Gender, Essence and the Feminine (Heptaméron 43," found in Lyons and McKinley (25-43), Hope Glidden proposes to read the 43rd tale as a challenge to the idea (often adopted by the Heptaméron storytellers) of "gender as a classificatory practice" (p. 26). She argues that Jambicque's success comes from her assumption of the "libidinous male role" of one who sees without being seen (p. 33). Through an analysis of this protagonist's spying and use of darkness and masks to hide her face, Glidden concludes that Jambicque's power strategy is "couched in terms of the gaze" (p. 32). However, the notion that Jambicque can transfix and objectify others by looking without being looked upon is insufficient in itself to account for her mastery of various situations at court. In the end, her lover knows her face but cannot use this knowledge to his advantage because he is unable to use her name.

7. "La nature des pronoms" in Problèmes de linguistique générale, vol. 1 (Paris: Gallimard, 1966), pp. 251-257. Benveniste states, "Chaque instance d'emploi d'un nom se réfere à une notion constante et 'objective,' . . qui demeure toujours identique dans la représentation 
qu'elle éveille. Mais les instances d'emploi du je ne constituent pas une classe de référence ... Chaque $j e$ a sa référence propre, et correspond à un être unique, posé comme tel ... et [the "empty" signs of the first and second person] ne sont pas soumis à une condition de vérité" (pp. 252-254).

8. This obsession extends into literary history as well: in his 1559 edition of the Heptaméron, Claude Gruget substitutes "Camille" (the name of the Amazon?) for "Jambicque" throughout the tale (M. François, p. 482, n. 609).

9. La conversation conteuse: Les nouvelles de Marguerite de Navarre (Paris: Presses Universitaires de France, 1992).

10. Poétique et onomastique: L'exemple de la Renaissance (Geneva: Droz, 1977), p. 12. See also Colette Winn, "La dynamique appellative des femmes dans l' Heptaméron de Marguerite de Navarre," Romanic Review, 77 (1986): 209-218.

11. Trans. H. E. Butler, 4 vols., Loeb Classical Library (Cambridge: Harvard University Press, 1920-1922).

12. See note 5 .

13. "Je vous manderay seullement qu'il vous souvienne de ce que vous avez promis" (p. 298).

14. H. Glidden, Art. cit., p. 31.

15. "Sur des vers de Virgile," Essais, ed. Pierre Villey (1924; Paris: Presses Universitaires de France, 1978), p. 863.

16. Grammaire du Décaméron (The Hague: Mouton, 1969), p. 13.

17. John D. Lyons and Mary B. McKinley, "Critical Tales: An Epilogue" (in Lyons and McKinley, 263-280), p. 270. See also Lyons's account of the role of the witness in Heptaméron 1 in his Exemplum: The Rhetoric of Example in Early Modern France and Italy (Princeton: Princeton University Press, 1989), pp. 82-93.

18. Essais, ed. Pierre Villey, pp. 880-881.1 